\title{
Cooperation in the field of professional training of specialists in social work: experience of interaction between the UC SYD and NVSU
}

\author{
Elena Bauer $^{1, *}$ \\ ${ }^{1}$ History Sciences, Department for Pedagogy and Pedagogical and Social Education, 628605, Nizhnevartovsk, Russia
}

\begin{abstract}
Social work is a new independent type of professional activities that needs to be analyzed from theoretical and practical perspectives. The paper describes the experience of cooperation of the University College of Southern Denmark (UC SYD) and Nizhnevartovsk State University (NVSU) on the issue of professional training of specialists in the field of social work. The article shows that the academic mobility of students and teachers enriches practical experience of specialists involved in the transfer of knowledge; enables students to correlate advantages and difficulties of training; develops an idea of unchanging requirements for the profession throughout the world. The results of cooperation are reflected in practical and theoretical planes and presented in the article.
\end{abstract}

\section{Introduction}

In 2019, the social service system of the KhantyMansiysk Autonomous District celebrates its 100th anniversary. The anniversary date draws attention of the public and specialists to methods of providing assistance to citizens and social groups, ways to overcome difficult life situations, and stages of development of social work as a profession. However, the ideas of mercy, charity, and help permeate the history. In the middle of the last century, special UN resolutions defined social work as a professional activity providing social services and assistance to those in need. Since then, development of training practices has begun. In Russia, the training of specialists in social work began in 1991. The multidisciplinary nature of the training direction allows using achievements of various fields - sociology, history, ethics, medicine, psychology, pedagogy, etc., and combining various models, technologies and methods developed by different states.

The UN World Program has defined education as one of the most important priorities of youth policy, which guarantees professional growth and active work [1]. The principle of academic mobility can enrich the modern system of training and expand an understanding of the structure of foreign professional education, as well as approaches and forms of training. NVSU was founded in 1988. It is one of the leading universities in the KhantyMansiysk Autonomous District. Since 2013, NVSU and UC SYD have had successful experience in international cooperation within the Erasmus + European Union Program. The university is the base platform for teaching European students; students and teachers can gain experience in teaching and analyze foreign practices.
The search for effective technologies used in working with various categories of the population, the generalization of models of social work management, the analysis of effective practices attract attention of researchers. The solution determines quality of training of specialists and development of scientific ideas on methods, forms, and approaches used in social work.

\section{Discussion}

In studying the foreign experience of social work, students and teachers deal with the problem of sources. Nevertheless, some aspects of vocational training in different countries are studied by Russian and foreign authors.

First, the authors describe models and practices of training in the field of social work, discuss the inclusion of some learning elements. For example, E.N. Lvov analyzed theoretical researches and practical experience of India, Great Britain, Australia, USA, Western Europe over the past twenty years. The author identified four training models, each of which demonstrates a special approach to the development of practical skills obtained in the course of involving students in direct activities the model of personal growth, the student's model, the managerial model, and the structured learning model [2]. E.N. Lvov emphasizes that the elements can be included in the domestic system of training specialists. N.M. Platonova describes modern approaches to the analysis of international experience in teaching social work [3]. K.M. Oganyan analyzed the extensive international experience in social work, including the problems of training students [4]. Summing up the results of many years of internships (at Stockholm University - the

\footnotetext{
Corresponding author: Bauerea@yandex.ru
} 
Higher School of Social Work; Frankfurt am Main State University; B. Pascal French University; Copenhagen University and Helsinki University), the author described a role of international associations, centers of social cooperation for training specialists. V.V. Bogatov who described the exchanging experience in social work aimed at protecting children and youth of Israel states that the priority direction is activities of public organizations; "professional training of social workers, as well as their practical activities, are based on psychological and psychological correction activities" [5].

Secondly, it is worth paying attention to studies on the social training system in Denmark. S. Juliusdottir and J. Peterssson described the practice of training specialists in social work in Northern Europe - Sweden, Norway, Finland, Denmark, Iceland [6]. In 2003, the authors wrote about significant differences in training students in these countries and came to the conclusion that there are no uniform educational approaches. They identified two main models of education - specialized practice and research-oriented education which could form one idealized training model - a model of integrated practice [6]. As the authors note, training in social work in Denmark, as in Norway, developed without interconnection with the academic community, but relied more on the formation of practical skills necessary to solve professional problems [6]. A.Yu. Lukyanova (Associate Professor, University College Absalon, Roskilde, Kingdom of Denmark) overviews the development of professional social work in conjunction with the development of a social protection system [7]. The modern concept of social work is reoriented "towards prevention, earlier intervention, introduction of scientific methods of social work and regular monitoring of social programs" [7]. E.A. Morozov focuses on the problem of practical training of future specialists in the social sphere. Comparing the ratio of theoretical and practical parts of training in Russia and Hungary, Switzerland, Germany, Great Britain, and Denmark, the author states that the share of practical activities is quite large and amounts to up to one third of the entire training time [8].

Thus, we can conclude that the problem under consideration is understudied. Traditional training practices do not overcome barriers of national borders, remain within educational institutions, which significantly narrows the idea about similarities and differences of models. The organization of practice, ways to enhance cognitive activities, technologies for evaluating performance, and forms of control are still a debatable issue.

\section{Results}

The result of cooperation between educational institutions was regular professional contacts of teachers and students: participation in competitions of the European Union's Erasmus + 2014-2020 program, key area 1: Individual mobility of students and teachers (as part of the inter-institutional agreement between NVSU and UC SYD for 2017-2019). In May 2019, the author, being a grant holder, delivered a lecture on the "Experience with disabled children and their families in Russia (using the Khanty-Mansiysk Autonomous District as an example) during her short-term internship at UC SYD. The content of the lecture was arranged in such a way as to meet training requirements for Danish students as part of the specialized module 9 A "Family and Children" (Esbjerg campus). Due to the internship, it was possible to collect and analyze materials on the participation of state and public structures in solving family problems in Denmark. A review of activities of institutions and the content of their work became the basis for teaching materials for the disciplines "The system of social protection of childhood", "Foreign experience of social work"; the materials were presented at the international conference by the results of the Jean Monnet's project.

Every year, two UC SYD students studying "Social Education" and "Social Work" are trained at the Faculty of Pedagogy and Psychology of NVSU. Students describe management of social services, forms and methods of social activities in Russia interact with their Russian colleagues and recipients of social services. The range of institutions for their internship is wide and covers activities with various categories of clients disabled children, elderly citizens, families who are in socially dangerous situations. At the same time, students of the Faculty of Pedagogy and Psychology studied at the UC SYD. They taught in "Crossing the Borders: Cultural Diversity in The Early Years of Education" (August-December 2018).

Close relationship between the academic community and practitioners resulted in joint activities - participation in contests of the Jean Monnet international project, whose issues were various types of assistance to family members in difficult life situations:

- «Crossing Borders: Cultural Diversity in Early Years Education» (2018).

- "European experience of social work with families" (2017),

- "Social work with families: analysis of the best European practices" (2018),

- "Integration of family issues into social policy: best practices of the European Union" (2019).

The following events contributed to the process of professional training of undergraduate students in Social Work:

- the round table on the topic: "The Danish Social Services System" (May 2017),

- the workshop "The system of professional training of specialists in Russia and Denmark: opportunities for academic mobility of students" (April 2018),

- the public lecture "The family is in the focus of attention of the state and society of Denmark" as part of VSU Science Week (February 2019),

- the Day of Danish Culture at NVSU (March 2019),

- International scientific-practical conference "Intercultural dialogue and cooperation between the EU and Russia: implementation of Jean Monnet projects in NVSU" (April 2019). 
Faculty teachers take part in the process of implementing practical activities and publish articles analyzing solutions to the the problem.

The joint work by N.L. Zhmakina, I.S. Teleginoy (Russia) and Martin H. Brunsgaard (Denmark) sheds light on the organization of student internships [9]. Based on targeted competencies, the authors developed a plan for internships of Danish students during their studies in Russia; theoretical approaches to its implementation were described.

The article by E.A. Bauer (Russia) and M. Neigaard (Denmark) lists reasons for applying foreign experience in training specialists in the field of social work: 1) insufficient coverage of the issue in the domestic scientific literature; 2) the need to identify features of the system of training students of different states; 3) the need for comparative studies in this area [10]. As a result, based on the analysis of regulatory documents and statistical data, they got acquainted with the system of training specialists in the field of social work in Denmark.

\section{Conclusion}

The interaction between the UC SYD and NVSU is expanding. On the one hand, the academic mobility allows us to learn the modern system of training of qualified personnel, determine organizational and methodological foundations of activities, and expand the professional cooperation. On the other hand, the study of scientific approaches used in other countries enriches technologies, forms, models of social work with various groups of the population. In addition, close cooperation motivates teachers and students to acquire quality knowledge, and expands the range of sources for the disciplines "Foreign experience of social work", "Fundamentals of social education".

Having analyzed the training of specialists in the field of social work in Denmark, we identified significant differences. First of all, they relate to national training requirements. The UC SYD is guided by the
Professional Baccalaureate Program for Social Work in accordance with the order of the Ministry of Education which determines the content of competencies, distribution of credit units, and the field of study. The result of training is knowledge, skills and the following competencies [11]:

1) establishment, maintenance and termination of professional relations with citizens, including interaction and cooperation with various target groups,

2) taking into account the basics of social policy to solve social or labor problems,

3 ) work with conflicting requirements and expectations of citizens, various groups of specialists and partners, development of recommendations in the field of social policy,

4) determination of social benefits, taking into account citizen's resources,

5) independent implementation and coordination of cooperation projects,

6) recognition of own training needs and structuring of knowledge

The basis of professional training is documents regulating activities of educational institutions, as well as academic traditions. We found that the training is structured in such a way that main professional competencies are developed during one year and 3 months; the specialization period lasts 2 years and 3 months. Thus, during three and a half years, the student can obtain a professional bachelor's degree, which makes it possible to apply for the master's degree. The UC SYD curriculum includes thirteen modules, topics are distributed by years, terms and credit units. The content of compulsory training modules includes specialization in one of the areas (compulsory parts of the program): Social and educational work with disabled children and youth; Social and educational work in the field of employment; Inter-professional content of social work. The total volume of the program is 210 credit units, of which $130 \mathrm{CU}$ are allocated to compulsory training modules. Additional program elements are presented in Table

Table 1. Elements of a training program for social workers

\begin{tabular}{|l|l|c|}
\hline No. & \multicolumn{1}{|c|}{ Field } & Number of CU \\
\hline 1. & Internship & 30 \\
\hline 2. & Optional module A or B & 15 \\
\hline 3. & Other optional modules & 15 \\
\hline 4. & Bachelor's project & 20 \\
\hline & Total & 80 \\
\hline
\end{tabular}

In addition, we found out that the main form of student work is a group one. The learning process is structured so that the pursuit of a common result is achieved through the distribution of roles. The distance communication format and information technologies are welcomed.

Practical training during four periods is crucial. Table 2 compares periods and duration of internship in NVSU and the UC SYD: 
Table 2. Periods and duration of internship in UC SYD and NSU

\begin{tabular}{|c|c|c|c|c|c|}
\hline \multirow[b]{2}{*}{ University } & \multicolumn{4}{|c|}{ Term, duration of internship } & \multirow{2}{*}{5} \\
\hline & 1 & 2 & 3 & 4 & \\
\hline UC SYD & $\begin{array}{c}2 \text { term and } 7 \\
\text { weeks }\end{array}$ & $\begin{array}{l}3-4 \text { terms and } \\
6 \text { months }\end{array}$ & $\begin{array}{c}5-6 \text { terms and } 6 \\
\text { months }\end{array}$ & 3-4 weeks & - \\
\hline NVSU & $\begin{array}{l}3 \text { terms } \\
\text { and } 2 \text { weeks }\end{array}$ & $\begin{array}{l}4 \text { terms } \\
\text { and } 3 \text { weeks }\end{array}$ & $\begin{array}{l}6 \text { terms } \\
\text { and } 4 \text { weeks }\end{array}$ & $\begin{array}{l}7 \text { terms } \\
\text { and } 4 \text { weeks }\end{array}$ & $\begin{array}{c}8 \text { terms } \\
\text { and } 4 \text { weeks }\end{array}$ \\
\hline
\end{tabular}

A comparative analysis of the results allows us to conclude that in the UC SYD, the training is practiceoriented and the amount of time allocated for internships in social institutions is larger than in Russia. At the same time, educational institutions of two countries take into account wishes of students concerning the location, type of a social institution, and the nature of its activities.

Further employment is possible in the public sector - the state administration, employment centers, hospitals, social institutions, prisons, or non-governmental institutions.

Despite the differences, the training of specialists in social work is based on common moral and ethical requirements: social activity, humanity, competence, confidentiality, responsibility, respect for colleagues, clients, and profession. There are similar requirements to final qualification projects which should deal with relevant problems of social work. The student has to show his/her ability to use knowledge obtained in the learning process based on scientific methods. The student can work on a bachelor's project in a private or public company. Social work as a professional activity determines required knowledge of regulatory documents.

\section{References}

1. E. Bauer, A. Salavatova, R. Shikhaliyev.. Advances in Social Science, Education and Humanities Research, The Educational Environment of the University as a Means of Preventing the Ideology of Extremism Among Young People. 288, 216-219. Retrieved from: http://apps.webofknowledge.com/full record.do?pro duct $=$ WOS\&search mode $=$ GeneralSearch\&qid $=2 \& S$ $\underline{\mathrm{ID}=\mathrm{E} 5 \mathrm{VKtNs} 8 \mathrm{ETH} 15 \mathrm{aHtQPG} \& \mathrm{page}=2 \& \mathrm{doc}=12}$.

2. E.N Lvova, Modern concepts and models of vocational and practical training in social work in Russia and abroad, 1, 102-107. (2011)

3. N. M. Platonova. Fundamentals of social education: a training manual, (St. Petersburg: St. Petersburg State
Institute of Sociology and Social Development. 2013)

4. K.M. Oganyan. Social Work Abroad: International Experience and the Swedish Model (St. Petersburg: St. Petersburg State University of Economics. 2016)

5. V.V Bogatov, Scientific and methodological approaches to educational training programs in modern conditions. Collection of articles of the III Regional Interuniversity Scientific and Practical Conference, Student practice in the exchange of experience in social work with children and youth abroad, 217-220. (2016)

6. S. Juliusdottir, Y. Petersson. Journal of Social Policy Studies. General standards for education in the field of social work in the countries of Northern Europe: to the statement of the problem, 2(3), 399-420. (2004)

7. A.Yu. Lukyanov. Social Protection and Professional Social Work in Denmark: A Brief Historical Review, Bulletin of the East Siberian Open Academy,14 (14), 6.(2014)

8. E.A Morozov, On practical training of specialists in social work Bulletin of Tomsk State Pedagogical University. 4 (106), 151-155.(2011)

9. N.L. Zhmakina, I.S. Telegin, Brunsgaard Martin H. Organization of industrial practice for students of University College of Southern Denmark as part of academic mobility, Bulletin of Nizhnevartovsk State University, Simbirsk Scientific Bulletin, 2, 21-27, (2018)

10. E.A. Bauer, M Neigaard, Bulletin of Nizhnevartovsk State University, Training of specialists in the field of social work in Denmark (from the experience of academic mobility of the NSU and UC SYD), 1, 1017. (2019)

11. Bekendtgørelse om uddannelse til professionsbachelor som socialrådgiver Retrieved from:

https://www.retsinformation.dk/Forms/R0710.aspx?i $\mathrm{d}=137840 \# \mathrm{~K} 1$ (2011) 